\title{
A predator's perspective on causal links between climate change, physical forcing and ecosystem response
}

\author{
William R. Fraser ${ }^{1, *}$, Eileen E. Hofmann ${ }^{2}$ \\ ${ }^{1}$ Polar Oceans Research Group, PO Box 368, Sheridan, Montana 59749, USA \\ ${ }^{2}$ Center for Coastal Physical Oceanography, Department of Oceanography, Old Dominion University, Norfolk, \\ Virginia 23529, USA
}

\begin{abstract}
The mechanisms by which variability in sea ice cover and its effects on the demography of the Antarctic krill Euphausia superba cascade to other ecosystem components such as apex predators remain poorly understood at all spatial and temporal scales, yet these interactions are essential for understanding causal links between climate change, ecosystem response and resource monitoring and management in the Southern Ocean. To address some of these issues, we examined the longterm foraging responses of Adélie penguins Pygoscelis adeliae near Palmer Station, western Antarctic Peninsula, in relation to ice-induced changes in krill recruitment and availability. Our results suggest that (1) there is a direct, causal relationship between variability in ice cover, krill recruitment, prey availability and predator foraging ecology, (2) regional patterns and trends detected in this study are consistent with similar observations in areas as far north as South Georgia, and (3) largescale forcing associated with the Antarctic Circumpolar Wave may be governing ecological interactions between ice, krill and their predators in the western Antarctic Peninsula and Scotia Sea regions. Another implication of our analyses is that during the last 2 decades in particular, krill populations have been sustained by strong age classes that emerge episodically every 4 to 5 yr. This raises the possibility that cohort senescence has become an additional ecosystem stressor in an environment where ice conditions conducive to good krill recruitment are deteriorating due to climate warming. In exploring these interactions, our results suggest that at least 1 'senescence event' has already occurred in the western Antarctic Peninsula region, and it accounts for significant coherent decreases in krill abundance, predator populations and predator foraging and breeding performance. We propose that krill longevity should be incorporated into models that seek to identify and understand causal links between climate change, physical forcing and ecosystem response in the western Antarctic Peninsula region.
\end{abstract}

KEY WORDS: Antarctic Peninsula - Adélie penguin - Antarctic krill · Climate warming · Sea ice · Antarctic Circumpolar Wave $\cdot$ Foraging ecology $\cdot$ Population structure $\cdot$ Longevity

Resale or republication not permitted without written consent of the publisher -

\section{INTRODUCTION}

Since the hypothesis was advanced early in the last decade that a decrease in winter sea ice in the western Antarctic Peninsula, WAP (see Fig. 1) due to climate warming was a major factor driving long-term change in the relative abundance of some regional, krilldependent predator populations (Fraser et al. 1992), several independent studies have significantly en- hanced our understanding of the dynamics addressed by this hypothesis. These studies converge on at least 3 relevant topics: the nature and magnitude of the warming trend, its consequences to sea ice development, and the effects of interactions between these 2 variables on ecosystem processes.

Recent analyses of long-term surface air-temperature records, for example, indicate that although the WAP has been warming since at least the mid-1950s 
(Smith et al. 1996, King \& Turner 1997), it is midwinter warming in particular that shows the only statistically significant increase (nearly $6^{\circ} \mathrm{C}$ over the last 56 yr; Smith et al. 2003). Trends showing a statistically significant anti-correlation between air temperature and sea ice extent have also been detected (Smith \& Stammerjohn 2001), and at least 2 regional studies now support the hypothesized decrease in winter sea ice due to climate warming (cf. Fraser et al. 1992). Work by Jacobs \& Comiso (1997) revealed that in the 2 decades following 1973, sea ice extent decreased by $20 \%$ as a recession that encompassed both winter and summer sea ice. Recent analyses by Smith et al. (2002) show that apart from a decrease in sea ice extent, sea ice during the last decade in particular has also been forming later and retreating earlier, resulting in a nearly $2 \mathrm{wk}$ decrease in the total duration of the sea ice season compared to conditions 50 yr ago.

Understanding how these trends may affect WAP marine ecosystem processes has focused primarily on the significance of sea ice to the Antarctic krill and the significance of krill to the marine food web. Krill are a dominant food-web component in the WAP marine system, and play a critical role in the transfer of energy between primary producers and secondary consumers (Laws 1985). Changes in krill distribution and abundance are thus 2 of the factors that can profoundly impact food-web interactions (Priddle et al. 1988, Fraser \& Trivelpiece 1996, Karl et al. 1996, Atkinson et al. 1999, Murphy \& Reid 2001, Reid \& Croxall 2001). The significance of sea ice to krill ensues from evidence that, unlike adults, larval krill cannot endure long periods without feeding (Quetin \& Ross 1991, Ross \& Quetin 1991). Winter survival when primary production is low thus depends, at least in part, on the availability of under-ice algae (Daly 1990), and several recent WAP studies have not only shown that cohort strength in krill is tightly coupled to sea ice conditions during the preceding winter (Kawaguchi \& Satake 1994, Fraser \& Trivelpiece 1995a,b, Siegel \& Loeb 1995, Loeb et al. 1997, Siegel et al. 1997, 1998), but that an order of magnitude decrease in krill abundance has occurred in the northern WAP during the last decade (Siegel \& Loeb 1995, Loeb et al. 1997, Siegel et al. 1997, 1998).

The belief that these interactions are essential to understanding causal links between climate change, ecosystem response, and resource monitoring and management in this marine system has now emerged as a new consensus in Southern Ocean ecological research (Fraser et al. 1992, Murphy et al. 1995, Fraser \& Trivelpiece 1996, White \& Peterson 1996, Loeb et al. 1997, Smith et al. 1999, Murphy \& Reid 2001, Reid \& Croxall 2001). However, while consider- able progress has been made in the area of krill-seaice interactions, the mechanisms by which variability in sea ice cover and its effects on krill demography cascade to other ecosystem components such as apex predators remain poorly understood at all spatial and temporal scales (Murphy et al. 1988, Murphy 1995, Reid et al. 1999b). It is this area that we explore in this paper.

Our analysis is focused on Adélie penguin foraging ecology. Adélie penguins are a sea-ice-dependent species throughout their circumpolar range (Ainley et al. 1983, 1994, Fraser et al. 1992, Fraser \& Trivelpiece 1996), but only in the mid- to northern WAP is the diet of this species dominated by Euphausia superba (Volkman et al. 1980, Fraser \& Trivelpiece 1996). In continental Antarctica, Adélie penguins rely more on the Antarctic silverfish Pleuragramma antarcticum and the krill E. crystallorophias, 2 species with a more on-shelf distribution than E. superba (Clarke et al. 1998, Ainley 2002). Compared to continental Antarctica, the WAP continental shelf is very narrow, sea ice is less prevalent annually, and important hydrographic features such as Circumpolar Deep Water (the most voluminous water mass carried by the Antarctic Circumpolar Current) occur relatively close to shore (Hofmann et al. 1996, Stammerjohn \& Smith 1996). The populations of krill that occur in the WAP are also thought to influence the marine ecosystem as far north as South Georgia (Hofmann et al. 1998, Murphy et al. 1998), meaning that the ecological setting for this study potentially encompasses one of the 'source' regions of large-scale variability. The processes and models we discuss, therefore, are circumscribed by rather unique physical and biological conditions that are atypical of continental Antarctica.

In this paper, we analyze concurrent data on WAP sea ice variability, Adélie penguin diets and foraging trip durations with the object of relating our findings to the broader issue of WAP food web dynamics, and specifically to the question of how Adélie penguin foraging ecology responds to ice-induced changes in krill demography. Our approach is conceptually focused on the predator's 'perspective' of its prey field, a paradigm that we suggest provides clues to system dynamics not immediately obvious within the scope of currently accepted models of krill life-history and predator-krill interactions. Our results imply a direct, causal relationship between variability in ice cover, krill recruitment, krill availability and Adélie penguin foraging ecology. However, based on patterns evident in the diet, we argue that understanding how these interactions cascade through the food web may require a reassessment of critical aspects of krill life-history and their significance to krill demography. 


\section{MATERIALS AND METHODS}

Study site and predator foraging. The data were obtained near Palmer Station $\left(64^{\circ} 46^{\prime} \mathrm{S}, 64^{\circ} 04^{\prime} \mathrm{W}\right)$, Anvers Island, western Antarctic Peninsula (Fig. 1). Research on Adélie penguins began in the early 1970s (Parmelee 1992), and since the late 1980s has continued in support of 2 long-term research and monitoring programs. An approach shared by these programs is

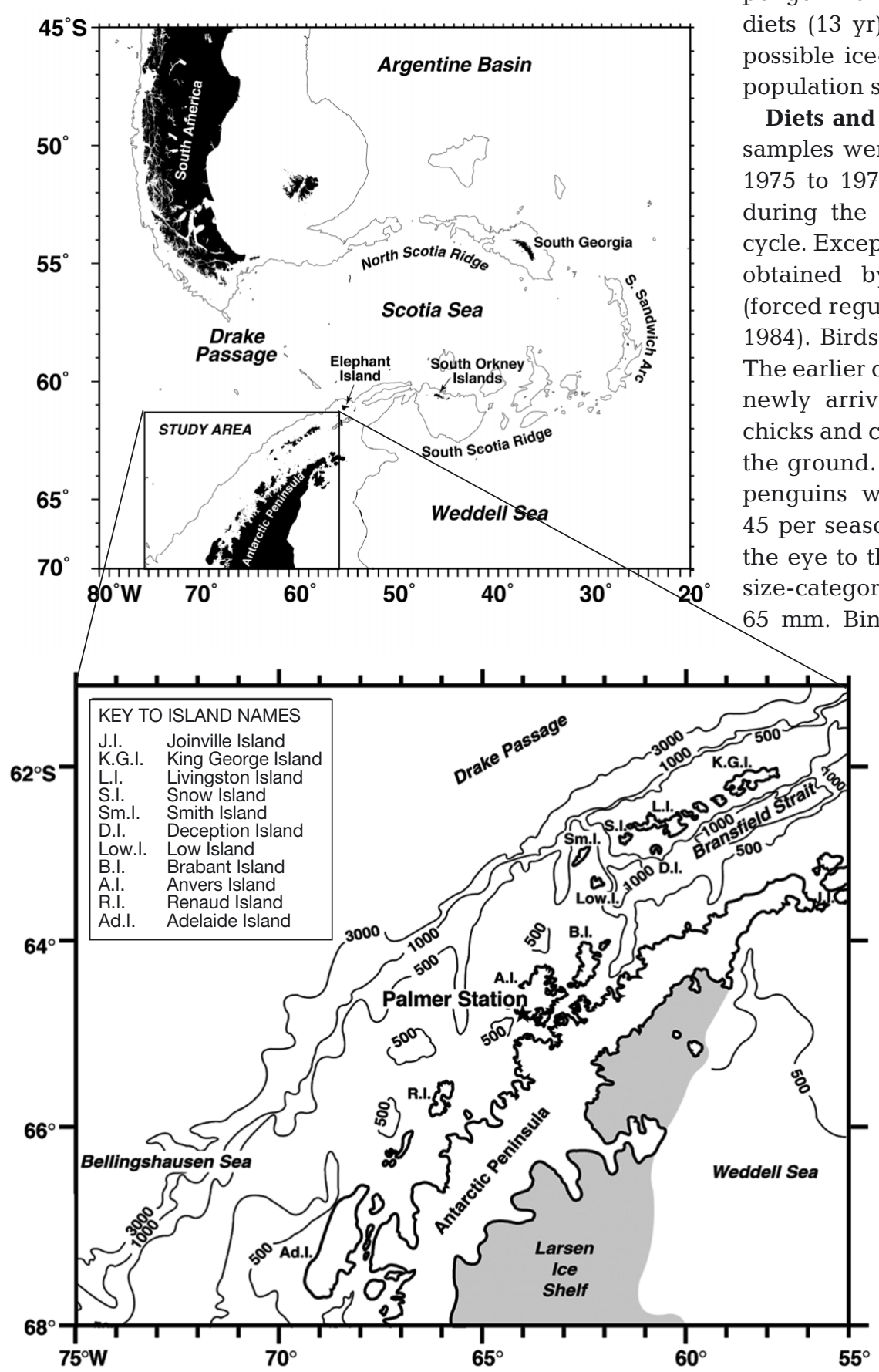

Fig. 1. Palmer Station and the western Antarctic Peninsula and Scotia Sea regions the use of penguin foraging ecology as an indicator of krill variability (see Fraser et al. 1988, Smith et al. 1995), and indeed many studies show that seabirds are good proxy indicators of the spatial and temporal variance associated with the structure of their prey populations (Sunada et al. 1981, Cairns 1987, 1992, Furness \& Nettleship 1991, Hatch \& Sanger 1992, Ainley et al. 1993, Croxall et al. 1999, Reid et al. 1999a,b). The penguin data analyzed include a time series on Adélie penguin foraging trip durations (8 yr) and another on diets $(13 \mathrm{yr})$, which we use as proxies to investigate possible ice-induced changes in krill availability and population size-class structure, respectively.

Diets and krill population size-class structure. Diet samples were obtained during January and February 975 to 1977 and 1988 to 1997 from adult penguins (forced regurgitation through stomach larvage; Wilson 1984). Birds were released unharmed after sampling. The earlier dietary samples were taken by interrupting newly arrived parents as they began to feed their chicks and collecting the regurgitate when it spilled on the ground. Regardless of methodology, 4 to 5 Adélie penguins were sampled at weekly intervals (30 to 5 per season). Krill were measured from the base of eye to the tip of the telson and assigned to 1 of 8 allow the pooling of historical and modern data which, for the 1988 to 1991 period, was available only in $5 \mathrm{~mm}$ summary form. Because krill grow more than $5 \mathrm{~mm} \mathrm{yr}^{-1}$ (Siegel 1987), this binning still resolves changes in population size-class structure that occur between years. Only whole, fresh krill originating from the upper portion of the stomach were measured. These typically are the first to be off-loaded or regurgitated (in the case of the earlier methodology), and their fresh state clearly separates them from the more digested layers that often follow. In all cases, the krill measured represented a subsample obtained by sorting through the entire fresh sample to ensure that smaller specimens were not overlooked; 50 to 100 krill were typically measured in each subsample.

Krill size-frequency distributions were developed from these subsamples and analyzed in a log-linear model framework with residual analysis (adjusted standardized residuals) using SYSTAT, 
Version 5 (Systat, Evanston, IL, USA) to reveal any patterns (Fienberg 1980). We used these data to test 2 related hypotheses: (1) to examine if the sizefrequency distributions of krill obtained by Adélie penguins changed in response to annual winter variability in sea ice conditions, we used a chi-squared test to test the null hypothesis that krill size classes in penguin diets follow a multinomial distribution regardless of field season; (2) to examine if the size-frequency distributions of krill obtained by Adélie penguins changed in response to cyclical variability in winter sea ice conditions, we used a chi-squared test to test the null hypothesis that krill size classes in penguin diets follow a multinomial distribution regardless of winter category. This last hypothesis was tested by divorcing the diet data from the temporal constraints imposed by year-specific classification and reclassifying them to reflect common environmental elements (i.e. sea ice conditions; Fienberg 1980). Winters during which mean September sea ice extent reached at least $60^{\circ} 50^{\prime} \mathrm{S}$ (see sea ice and prey indices in later subsections), or the northern perimeter of the WAP, were thus categorized as Class 1 ice years (the beginning of an ice cycle), and the winters following until the next ice maximum as Class $2 \ldots \mathrm{N}$ ice years (Table 1 ). The term 'good recruitment' is used to infer that krill in the 16 to $25 \mathrm{~mm}$ size class were significantly more abundant than predicted by the null hypothesis in the loglinear model. Krill in this size class represent the 1+ age class (Siegel 1987, Siegel et al. 2002), or the age class upon which most indices of krill recruitment success are based (Siegel \& Loeb 1995, Loeb et al. 1997, Siegel et al. 1997, 1998, 2002). Additionally, the term

Table 1. Field seasons categorized according to winter ice class at Palmer Station. Class 1 ice winters (bold face) signal the beginning of an ice cycle for analytical purposes and are based on the patterns of change in sea ice extent in Fig. 2. 1974/75 field season is categorized as Class 5 based on surface air temperature-sea-ice-extent relationships reported by Fraser et al. (1992) and Loeb et al. (1997)

\begin{tabular}{|lccc|}
\hline Field season & Ice class & Field season & Ice class \\
\hline $1974 / 75$ & 5 & $\mathbf{1 9 8 6} / 87$ & $\mathbf{1}$ \\
$\mathbf{1 9 7 5 / 7 6}$ & $\mathbf{1}$ & $1987 / 88$ & 2 \\
$1976 / 77$ & 2 & $1988 / 89$ & 3 \\
$1977 / 78$ & 3 & $1989 / 90$ & 4 \\
$1978 / 79$ & 4 & $\mathbf{1 9 9 0 / 9 1}$ & $\mathbf{1}$ \\
$1979 / 80$ & 5 & $1991 / 92$ & 2 \\
$\mathbf{1 9 8 0} / 81$ & $\mathbf{1}$ & $1992 / 93$ & 3 \\
$1981 / 82$ & 2 & $1993 / 94$ & 4 \\
$1982 / 83$ & 3 & $\mathbf{1 9 9 4} / 95$ & $\mathbf{1}$ \\
$1983 / 84$ & 4 & $1995 / 96$ & 2 \\
$1984 / 85$ & 5 & $1996 / 97$ & 3 \\
$1985 / 86$ & 6 & & \\
\hline
\end{tabular}

'cohort' is used to refer to Age 1+ krill, which convention recognizes may include 1 to $2 \mathrm{yr}$ old individuals (Siegel 1987).

Duration of foraging trips. Foraging trip durations were determined annually during January 1990 to 1997 by tagging 30 to 40 adult penguins with $13 \mathrm{~g}$ radio transmitters (Advanced Telemetry Systems, Isanti, MN, USA). Tagged birds were typically brooding 7 to $10 \mathrm{~d}$ old chicks, and were selected for tagging only if their partners were present at the nest so their relative size could be compared and a gender assigned. Only 1 member of each pair was tagged, and pairs too similar in size to make a gender determination were omitted. This optimized preservation of an equal sex ratio among tagged birds, and ensured control over this factor in subsequent analyses (cf. Clarke et al. 1998, Ballard et al. 2001). Trip durations were calculated from data obtained using automatic data loggers set to record (date, $\mathrm{h}, \mathrm{min}$ ) the presence of tagged birds near their breeding colonies every $20 \mathrm{~min}$; foraging time at sea is thus inferred based on periods of absence from the colonies.

The foraging trip duration analyses observe several conditions. (1) To minimize the possibility that chick development stage between seasons would confound results (cf. Clarke et al. 1998), the data selected for analyses were standardized on the date when approximately $70 \%$ of the chicks were in crêche; this date varied between 10 and 26 January during the $8 \mathrm{yr}$ time series. (2) Data included in the analyses was restricted to two $5 \mathrm{~d}$ periods that centered on the crêche date, 1 period before and 1 period after this date. This ensured adequate sampling of the peak chick-growth phase, or the period when adults are likely to be under the greatest constraints to effectively provision their young (Fraser \& Ainley 1989, Salihoglu et al. 2001). The only exception in this procedure was the 1992 to 1993 field season, where a receiver malfunction limited the analysis to the last $5 \mathrm{~d}$ of this $10 \mathrm{~d}$ period. (3) To avoid bias in the analyses due to foraging trip frequency, the mean foraging trip duration for each $10 \mathrm{~d}$ period was developed from the means of individual trip durations for the period without weighting by number of trips (CCAMLR 1992). (4) Periods of absence of less than $3 \mathrm{~h}$ from the colonies by adult penguins were not considered in the analyses, as direct observations suggested that most birds are not likely to complete a foraging trip in less than $3 \mathrm{~h}$ (Fraser \& Trivelpiece 1996).

Sea ice indices. Sea ice trends were extended through 1996 by updating the index reported in Fraser et al. (1992) with weekly ice charts distributed through the US Navy-NOAA Joint Ice Center (now called the National Ice Center [NIC]; see www.natice.noaa.gov). These charts are compiled every $7 \mathrm{~d}$ and represent 
summaries of sea ice conditions derived by integrating the results of several remote-sensing technologies. Because of differences in the number of sensors used aboard the satellites that provided the data used to generate the older (pre-1978) and more recent (post1978) charts, researchers often only consider the more recent information when developing ice indices (e.g. Smith et al. 1998). However, Wilson et al. (2001) have shown that integrating older and newer remotesensing data did not skew the ice relationships being investigated (sea ice extent in the Ross Sea); we thus similarly assume that in updating our index, the results were compatible over the time series.

Our ice index is based on the northward position of the ice edge in September; this was calculated as the mean of the ice edge latitudes shown in the NIC $7 \mathrm{~d}$ ice charts along a line extending from the tip of South America to a point centered on $61^{\circ} \mathrm{S}$. The southern end-point of this line is just outside the northern boundary of the WAP (see Hofmann et al. 1996, p. 62), and the precedence for reporting sea ice variability in this manner is based on the study of Fraser et al. (1992, p. 526). In the latter study, regression analysis showed a highly significant relationship between surface air temperature and the mean northward position of the ice edge, such that winters with extensive ice are characterized by temperatures $\leq-4.3^{\circ} \mathrm{C}$ and an ice edge that reaches or exceeds $60^{\circ} 50^{\prime} \mathrm{S}$. September marks the end of sea ice advance in this region (Stammerjohn \& Smith 1996); hence, we used the mean northward position of the ice edge during September both as an index of annual change and as the basis for reclassifying the year-specific penguin-diet data to reflect common winter sea ice conditions (see diets and krill population size structure in earlier subsections).

Prey indices and simulations. We used models described by Priddle et al. (1988) and Murphy \& Reid (2001) in combination with a krill abundance index based on stratified mean densities from the Elephant Island $\left(61^{\circ} 10^{\prime} \mathrm{S}, 55^{\circ} 14^{\prime} \mathrm{W}\right)$ region just north of the WAP (e.g. Siegel \& Loeb 1995, Loeb et al. 1997, Siegel et al. 1997, 1998, 2002) to test hypotheses about changes in krill availability suggested by our analyses. The Elephant Island data were used in lieu of Palmer Station data because the time series on krill abundance for the latter does not include the first $2 \mathrm{yr}$ of our $8 \mathrm{yr}$ foraging trip duration time series (see Smith et al. 1995). Piece-wise linear regression models were used to investigate relationships between the Elephant Island krill-abundance trends and the foraging responses of Adélie penguins at Palmer Station.

\section{RESULTS}

\section{Sea ice extent}

Winter sea ice extent in the WAP exhibits high interannual variability but, as shown in Fig. 2, ice maxima are episodic and high-ice years are invariably followed by several low-ice years that together form a distinct series or cycle. We identified 5 such cycles between the 1973/74 and 1996/97 field seasons. These cycles began with the winters of 1975, 1980, 1986, 1990 and 1994, respectively, and each was characterized by an ice field that advanced to or beyond the northern boundary of the WAP (Fig. 1). The longest interval between high-ice years (6 yr) occurred during the 1980 to 1986 cycle, the 2 shortest intervals (4 yr) during 1986 to 1990 and 1990 to 1994, and an intermediate interval (5 yr) during 1975 to 1980. Together, these cycles occurred with an average frequency of $4.75 \mathrm{yr}$, with no indication of an ice maximum during the 1977 and 1978 gaps in the data based on air temperature-sea-ice relationships (Fraser et al. 1992, Loeb et al. 1997, Smith et al. 2003).
Fig. 2. Variability in sea ice extent during September in the western Antarctic Peninsula region between 1973 and 1996. Years in bold face mark beginning of ice cycles, or years during which sea ice in September reached or exceeded $61^{\circ} \mathrm{S}$. No satellite data were available for 1977 and 1978. (Data adapted and updated from Fraser et al. 1992)

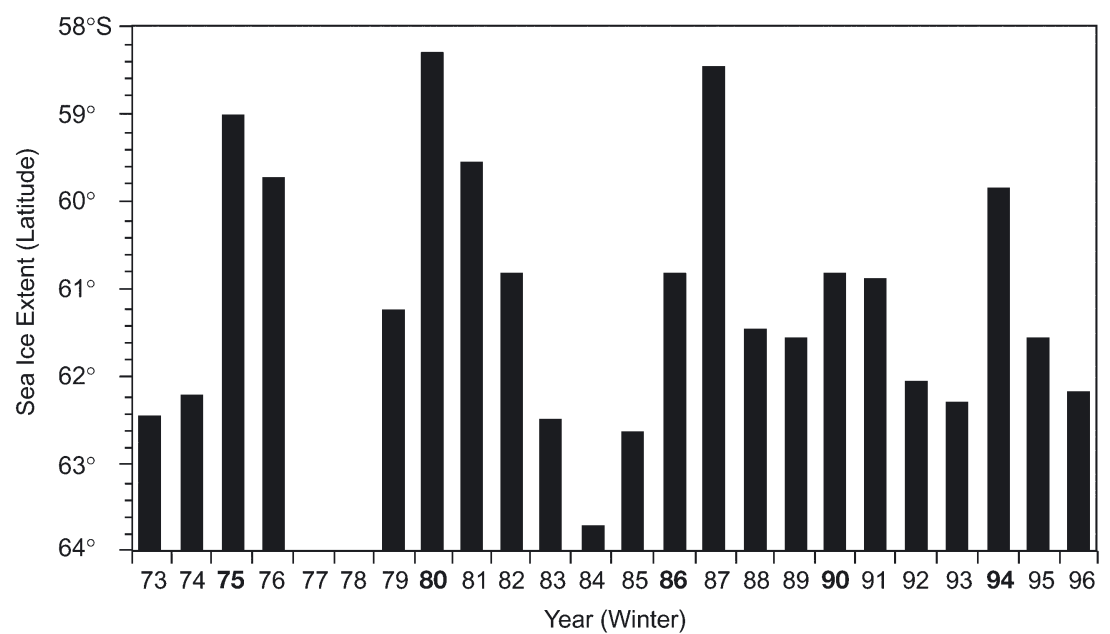


Table 2. Euphausia superba. Pattern of standardized residuals for the $1974 / 75$ to 1996/97 field seasons at Palmer Station. Large positive residuals indicate that cells had more krill than predicted by the null hypothesis. Size classes $16-20 \mathrm{~mm} / 21-25 \mathrm{~mm}$ and $56-60 \mathrm{~mm} / 61-65 \mathrm{~mm}$ combined because of low frequencies. For residuals $\geq 2.0, \alpha=0.05$; for residuals $\geq 3.0, \alpha=0.01$

\begin{tabular}{|lcccccccc|}
\hline \multirow{2}{*}{$\begin{array}{l}\text { Field } \\
\text { season }\end{array}$} & $16-25$ & $26-30$ & $31-35$ & $36-40$ & $41-45$ & $46-50$ & $51-55$ & $56-65$ \\
\hline $1974 / 75$ & & & & & 5.55 & 11.97 & & \\
$1975 / 76$ & & & & & & 18.64 & & 9.22 \\
$1976 / 77$ & 5.59 & & & & & & 15.25 & \\
$1987 / 88$ & 7.50 & & & & 3.40 & & 21.64 & \\
$1988 / 89$ & & 4.93 & & & & 7.15 & 13.69 & 10.57 \\
$1989 / 90$ & & 13.09 & 14.93 & 9.99 & & & & \\
$1990 / 91$ & & & & 2.49 & 4.00 & 3.67 & & \\
$1991 / 92$ & 2.50 & & & & 2.05 & 3.15 & 8.39 & 22.23 \\
$1992 / 93$ & & & 17.58 & 15.53 & & & & \\
$1993 / 94$ & & & & 8.16 & 20.05 & & & \\
$1994 / 95$ & & & & 10.66 & 16.24 & & & \\
$1995 / 96$ & 6.17 & & & & 7.88 & 13.88 & & \\
$1996 / 97$ & 8.49 & 16.43 & 37.63 & 10.24 & & & & \\
\hline
\end{tabular}

Table 3. Euphausia superba. Pattern of standardized residuals for each ice class category at Palmer Station. Large positive residuals indicate that cells had more krill than predicted by the null hypothesis. Size classes $16-20 \mathrm{~mm} / 21-25 \mathrm{~mm}$ and $56-60 \mathrm{~mm} / 61-65 \mathrm{~mm}$ combined because of low frequencies. For residuals $\geq 2.0, \alpha=0.05$; for residuals $\geq 3.0, \alpha=0.01$

\begin{tabular}{|lcccccccc|}
\hline \multirow{2}{*}{$\begin{array}{l}\text { Ice } \\
\text { class }\end{array}$} & $16-25$ & $26-30$ & $31-35$ & $36-40$ & $41-45$ & $46-50$ & $51-55$ & $56-65$ \\
\hline 1 & & & & & 7.75 & 20.73 & & \\
2 & 8.03 & & & & & 5.26 & 26.36 & 12.15 \\
3 & & 11.54 & 27.83 & 8.83 & & & & \\
4 & & & & 12.63 & 12.00 & & & \\
5 & & & & & 5.55 & 11.97 & & \\
\hline
\end{tabular}

\section{Trends in krill size class}

\section{Comparisons between field seasons}

The null hypothesis that krill size classes in penguin diets follow a multinomial distribution regardless of field season was rejected $\left(\chi^{2}=10146\right.$, G-test $=$ 10283 , df $=72, \mathrm{p}<0.001)$, and the standardized residuals were examined for patterns (Table 2). There were 2 trends associated with year-specific changes in sea ice extent: (1) The frequency of occurrence of the 16 to $25 \mathrm{~mm}$ size class (the 1+ age class), suggesting good recruitment, was statistically significant in the penguin diets only during 1976/77, 1987/88, 1991/92, 1995/96 and 1996/97, or the field seasons following sea ice extent maxima associated with the ice cycles that began with the winters of 1975, 1986, 1990 and 1994 (Fig. 2). Each ice cycle was associated with at least 1 recruitment event, the exception being 1994, when 2 of these events are recorded during sequential field seasons. (2) The second pattern issues from the first. Between ice maxima, the pattern of standardized residuals associated with the frequency of occurrence of the various size classes changes, with the larger $(>25 \mathrm{~mm})$ as opposed to the smaller (i.e. the 16 to $25 \mathrm{~mm}$ ) size classes becoming the statistically significant components of the diet (Table 2). Fig. 3 shows these trends for the continuous data that began with the 1987/88 field season. This time series began with predominately large krill (mode $=51$ to $55 \mathrm{~mm}$ ) in 1987/88 and ended with predominantly small krill (mode $=31$ to $35 \mathrm{~mm}$ ) in 1996/97. During the intervening decade, however, 2 quasi-independent patterns were evident in which predominantly smaller krill that emerged in the population following years of heavy ice were replaced by larger krill over a 3 to 4 yr period.

\section{Comparisons between ice cycles}

The null hypothesis that krill size classes follow a multinomial distribution regardless of winter category (Table 1) was rejected $\left(\chi^{2}=4767, G\right.$-test $=4437$, $\mathrm{df}=28, \mathrm{p}<0.001)$ and the standardized residuals were examined for patterns (Table 3). The trends apparent in Table 2 and Fig. 3 are confirmed in Table 3, with the relevant correlations more clearly expressed. Thus, the occurrence of the 16 to $25 \mathrm{~mm}$ size class $(1+$ age class), indicating good recruitment, became statistically significant only during Class 2 ice years, or following the second winter of an ice cycle. Beyond the second winter, the frequency of occurrence of specific size classes varied in accordance with the progression of the ice cycle, gradually shifting from smaller to larger krill through a 4 to 5 yr period.

\section{Adélie penguin foraging performance}

\section{Models and predictions}

Priddle et al. (1988) and Murphy \& Reid (2001) simulated the effects of failed recruitment years on krill population size-class structure (see also Reid et al. 1999a). In these simulations, 1 or more years of 


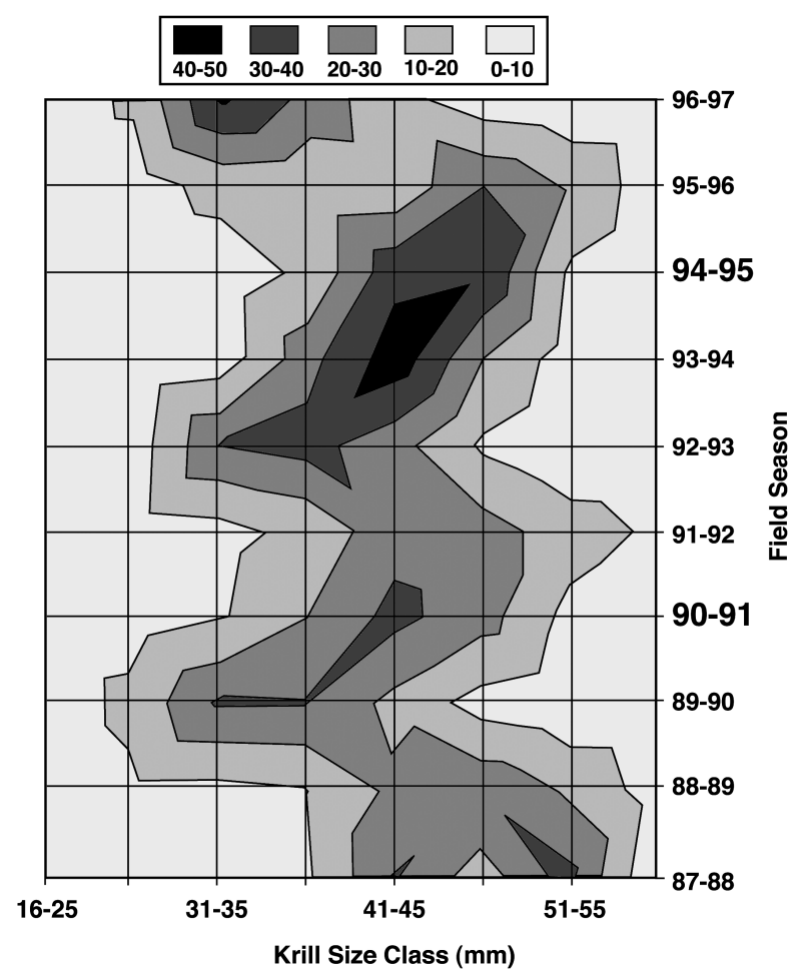

Fig. 3. Pygoscelis adeliae. Surface contour plot showing relative presence of krill Euphausia superba size classes between 1987/88 and 1996/97 field seasons in Adélie penguin diet samples near Palmer Station. Years in bold face mark beginning of ice cycles (based on data in Table 1)

recruitment failure tends to skew distributions towards the larger size classes, while years of good recruitment have the opposite effect. Also, because entire age groups may be absent from the population due to 1 or more recruitment failures, the simulations indicate that krill abundance tends to decrease following years of poor recruitment, and to increase following years of good recruitment. The relevance of these simulations is that they predict the direction of change (but not the magnitude) in krill size-class structure and abundance that should follow good and bad recruitment events. Therefore, if changes in krill abundance track the effects of krill size-class structure as suggested by these models, the patterns evident in Table 3 would predict that the duration of Adélie penguin foraging trips (FTDs) should be relatively long during Class 1 and 5 ice years, shortest during Class 2 ice years, and increase thereafter through Class 3 and 4 ice years.
Krill size-class structure, and variability in Adélie penguin foraging trip duration

Differences in mean FTDs (Table 4 ) were highly significant $(F=46.80, \mathrm{df}=7,238 ; \mathrm{p}<0.001)$, but variability agreed only in part with the changes in krill size-class structure suggested by Table 3 . As predicted, the longest mean FTDs $(1990 / 91,1994 / 95)$ were associated with the presence of predominantly large krill in Class 1 ice years, or the years that marked the beginning of the ice cycles that started with the 1990 and 1994 winters (Fig. 2). Class 5 ice year results are not available, as this category did not occur during the FTD time series. Mean FTDs also decreased significantly during Class 2 ice years (1991/92, 1995/96), the change predicted based on the presence of smaller (16 to $25 \mathrm{~mm}$ ) krill in the population due to good recruitment (Table 3). Although FTDs were expected to increase during Class 3 and 4 ice years, the observed changes generally did not agree with expectations, and only the 1989/90 season (Class 4 ice year of the 1986 ice cycle) exhibited a longer FTD.

Krill abundance proxies, and variability in Adélie penguin foraging trip durations

Of the 5 ice cycles covered in whole or in part by the Elephant Island krill abundance time series (Table 5), those beginning in 1980, 1990 and 1994 support the prediction that, within an ice cycle, Class 1 ice years should be associated with lower krill abundances and Class 2 ice years with higher abundances due to the influx of recruits. The 1980 and 1986 ice cycles support the additional prediction that krill abundances within

Table 4. Pygoscelis adeliae. Adélie penguin foraging trip durations near Palmer Station during January chick-feeding period. The 8 field seasons shown encompass all or part of the ice cycles that began with winters of 1986, 1990 and 1994. Ice classes as in Table 1 and Fig. 2; bold face marks beginning of an ice cycle. Significance values are based on post-hoc tests using Bonferroni adjustment, and represent comparisons of each season with that preceding. $\mathrm{N}$ : number of penguins foraging during the period; $\mathrm{n}$ : number of foraging trips completed ${ }_{i}-$ : no comparison made

\begin{tabular}{|lcrrcccc|}
\hline $\begin{array}{l}\text { Field } \\
\text { season }\end{array}$ & $\begin{array}{c}\text { Ice } \\
\text { class }\end{array}$ & $\begin{array}{c}\text { Mean } \\
\text { (h) }\end{array}$ & SD & Significance & $\mathrm{N}$ & $\mathrm{n}$ \\
\hline $1989 / 90$ & 4 & 14.33 & 5.44 & - & 23 & 207 \\
$\mathbf{1 9 9 0 / 9 1}$ & $\mathbf{1}$ & 25.82 & 12.11 & 0.000 & 22 & 141 \\
$1991 / 92$ & 2 & 9.22 & 1.95 & 0.000 & 34 & 459 \\
$1992 / 93$ & 3 & 8.19 & 2.17 & 1.000 & 31 & 220 \\
$1993 / 94$ & 4 & 8.99 & 3.01 & 1.000 & 31 & 429 \\
$\mathbf{1 9 9 4} / 95$ & $\mathbf{1}$ & 25.02 & 8.41 & 0.000 & 38 & 293 \\
$1995 / 96$ & 2 & 12.39 & 5.50 & 0.000 & 32 & 201 \\
$1996 / 97$ & 3 & 9.34 & 2.79 & 0.976 & 34 & 361 \\
\hline
\end{tabular}


Table 5. Euphausia superba. Trends in estimated krill stock density (mean no. $/ 1000 \mathrm{~m}^{-3}$ ) in the Elephant Island region. Data are matched sequentially by rows and columns to illustrate changes within and between ice cycles. Ice classes (as in Table 1) reflect ice cycles beginning in 1975, 1980, 1986, 1990 and 1994. Values in bold face: density of krill stocks at the beginning of each ice cycle; nd: no data. (Table adapted from Loeb et al. [1997] and Siegel et al. [2002])

\begin{tabular}{|lrlllllrlrrr|}
\hline Ice class & \multicolumn{4}{c|}{ Field season } & \multicolumn{5}{c|}{ Krill stock density } \\
\hline 1 & 75 & 80 & 86 & 90 & 94 & nd & $\mathbf{4 9 . 5}$ & nd & $\mathbf{4 . 8}$ & $\mathbf{1 4 . 8}$ \\
2 & 76 & 81 & 87 & 91 & 95 & nd & 510.9 & 66.6 & 25.3 & 79.1 \\
3 & 77 & 82 & 88 & 92 & 96 & 132.9 & 90.6 & 41.7 & 26.6 & 270.8 \\
4 & 78 & 83 & 89 & 93 & & nd & 67.4 & 15.4 & 28.9 & \\
5 & 79 & 84 & & & & nd & 12.3 & & & \\
6 & & 85 & & & & nd & nd & & & \\
& & & & & & & & & & &
\end{tabular}

which show krill abundances in postClass 2 ice years as stable and increasing, respectively (Table 5).

Adélie penguin FTDs near Palmer Station varied in close agreement with changes in krill abundance near Elephant Island (Fig. 4a). As predicted based on the patterns in Table 3, Class 1 ice years 1990/91 and 1994/95 were associated with the longest FTDs and the 2 lowest measures of krill abundance, while the reverse was observed during Class 2 ice years 1991/92 and 1995/96, which showed large increases in krill abundance and significantly shorter FTDs. Although the FTDs associated with Class 3 and 4 ice years ice cycles should decrease during Class 3 and 4 ice years in the absence of new recruitment as the dominant cohort produced during the Class 2 ice year moves through the population. These trends, however, are not consistent with the 1990 and 1994 ice cycles,
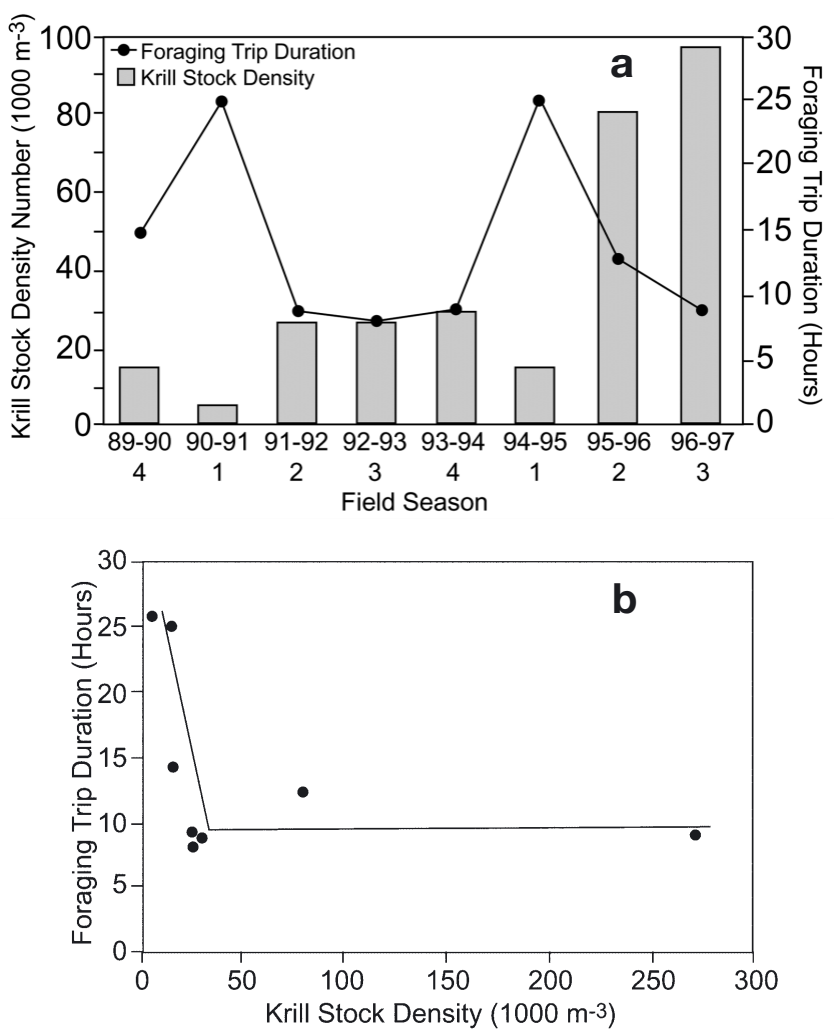

Fig. 4. Pygoscelis adeliae. (a) Variability in Adélie penguin foraging trip duration (line) near Palmer Station in relation to krill stock density (bars) near Elephant Island. Numbers below the field season designator are ice year classes. Data are adapted from Tables 4 \& 5. (b) Piece-wise linear regression model showing relationships between foraging trip duration near Palmer Station and krill Euphausia superba abundance near Elephant Island again showed the least agreement with expectations, they varied in accordance with the apparent changes in krill abundance (Fig. 4a). The relative magnitudes of the changes, however, were very different, suggesting an intrinsically non-linear relationship between krill abundance and FTD. This was confirmed with a piecewise linear regression model (Fig. 4b), which explained $81.76 \%$ of the variance $(p<0.01)$ and identified $a$ breakpoint or threshold in krill abundance at 25.94 $\left(1000 \mathrm{~m}^{-3}\right)$. The negative slope of the line before this breakpoint $(-0.8238)$ suggests that at krill abundances below $25.94\left(1000 \mathrm{~m}^{-3}\right)$, FTDs will increase as krill abundance decreases. The slope of the line after the breakpoint (0.0001) is in effect a plateau, indicating that FTDs will not continue to decrease with higher krill abundances; indeed, the analysis suggests that a mean FTD of $9.71 \mathrm{~h}$ was still required by penguins to forage when krill abundance was above $25.94\left(1000 \mathrm{~m}^{-3}\right)$.

\section{DISCUSSION}

\section{Sea ice extent}

Maxima in sea ice extent propagate eastwards around Antarctica in the form of 2 wavelengths that encircle the continent end-to-end, but that as individual phases take 8 to $10 \mathrm{yr}$ to return to their starting point (Murphy et al. 1995, White \& Peterson 1996). Variability in maximum sea ice extent at any particular location around the continent thus occurs on timescales of 4 to $5 \mathrm{yr}$. This is the periodicity of the ACW (Antarctic Circumpolar Wave) (White \& Peterson 1996). The patterns of sea ice variability observed in this study are consistent with this periodicity, taking the form of ice cycles that manifest regionally every 4 to 6 yr (Fig. 2, Table 1).

Adélie penguin foraging responses to this forcing reflect at least 3 related processes: the effects of sea ice 
on krill recruitment, the effects of krill recruitment on krill population size-class structure, and the effects of this structure on foraging performance. Although these processes in some cases appear as direct, causal interactions, this conclusion overlooks the full implications of the ACW on regional processes. Apart from sea ice extent, the ACW exhibits coherent anomalies in sea-surface temperature, meridional wind stress and atmospheric sea-level pressure (White \& Peterson 1996), suggesting that water column and other effects may play an additional causal role in the biology of the oceans influenced by the ACW (Peterson \& White 1998, Gloersen \& White 2001). In the WAP, episodic, across-shelf exchanges due to meanders of the Antarctic Circumpolar Current can influence sea ice formation through water temperature and salinity changes, and these, in turn, may have important (but lagged) effects on primary production and krill reproduction (Hofmann \& Klinck 1998, Klinck 1998, Prézelin et al. 2000). Thus, although sea ice extent is a reasonable proxy for investigating krill-predator interactions, it is only one manifestation of a host of associated processes that might explain variability in marine populations (e.g. Nicol et al. 2000). Some of these, especially as they relate to hydrography and other possible water column effects on krill, are discussed in Hofmann \& Fraser (2003). Below we focus the discussion on ice-krill-predator interactions.

\section{Krill population size-age structure}

The patterns evident in Table 3 suggest that the krill population encountered by Adélie penguins in the Palmer Station region was influenced by processes that produced a non-random size and age structure. This is implicit in the systematic increase in krill size classes as ice cycles progressed annually through an approximately 4 to $5 \mathrm{yr}$ period. Because multiple age classes would buffer the population from exhibiting these systematic changes (Priddle et al. 1988, Siegel et al. 1998, Reid et al. 1999a, Murphy \& Reid 2001), however, a key implication is that strong age classes exhibited a common pattern of rare occurrence during the time series integrated by the analyses. The concordance in periodicities between years of extensive winter sea ice in the WAP (Fig. 2), good krill recruitment (Table 2) and the progression of strong year classes through the population within ice cycles (Table 3 ) thus suggests that forcing by the ACW or ACW-like processes underlines the non-random structure of the krill population.

Although active selection by the predator could be another possible explanation for the apparent gaps in age classes observed in the data (Tables 2 \& 3), much of the available evidence points to passive (i.e. lack of availability in the foraging environment) selection as playing the dominant role. This conclusion is unambiguous in this study based strictly on the very large values and statistical significance of the residual patterns evident in Table 3. The best example is Class 2 ice years, in which the occurrence of the smallest krill size class (16 to $25 \mathrm{~mm}$ ) and its associated residual (8.03) was coherent with the largest krill (56 to $65 \mathrm{~mm}$ ) and some of the largest residual values recorded in the time series (26.36). Other studies support this conclusion. Systematic gaps due to missing age classes in krill population structure have been reported for the King George Island (Fraser \& Trivelpiece 1995a,b) and Elephant Island (Fig. 1; and Siegel et al. 1998, 2002) regions. These gaps also show a pattern of episodic recruitment every 4 to $5 \mathrm{yr}$, including intervening years in which age $1+$ krill are rare or completely absent. A third area in which similar processes have been observed is South Georgia (Fig. 1). Here, Reid et al. (2002) showed that, after adjusting for regional differences in growth and mortality, the size structure of the local krill population exhibited strong spatial and temporal coherence with recruitment events in the Elephant Island region. Especially relevant insofar as our own findings are concerned, however, is that during the decade (1991 to 2000) considered in their analyses, the Elephant Island area generated only 2 strong year classes (1990/91, 1994/95, see also Table 5), which Reid et al. (2002) noted were expressed simultaneously in the 2 regions in 1991/92 and 1995/96. If we add our results to these observations (Table 2), it appears that the strong krill year classes produced in response to the 1990 and 1994 ice cycles were expressed concurrently in at least 3 regions. This not only supports the idea that the gaps in krill age classes observed in our data were unrelated to active selection by Adélie penguins, it also suggests that the 4 to $5 \mathrm{yr}$ pattern of episodic, sea-ice-induced forcing of krill demography indicated by our analyses (Tables 2 \& 3) may have involved processes operating over scales that encompassed much of the Scotia Sea and WAP, at least as far south as Anvers Island.

A non-random size structure implies an analogous age structure, and because aspects of krill life-history with implications for distribution and abundance can be age-related (see following paragraphs), population age structure can offer important insights into factors that may affect predator foraging performance (Murphy et al. 1998, Murphy \& Reid 2001). A hypothetical age structure for a dominant krill cohort as it moves through the population within an ice cycle is shown in Table 6. Recognizing that difficulties exist in attributing size to age in krill, we have assumed that the size-age relationship of 16 to $25 \mathrm{~mm}$ krill (Age 1+) in 
Table 6. Euphausia superba. Hypothesized age of dominant krill cohort near Palmer Station during each year of an ice cycle. Rationale for these age classes is based on pattern of residuals in Table 3

\begin{tabular}{|c|c|c|c|c|c|c|c|c|}
\hline \multirow{2}{*}{$\begin{array}{l}\text { Ice } \\
\text { class }\end{array}$} & \multicolumn{8}{|c|}{ Krill size class (mm) } \\
\hline & $16-25$ & $26-30$ & $31-35$ & $36-40$ & $41-45$ & $46-50$ & $51-55$ & $56-65$ \\
\hline 1 & & & & & $5+$ & & & \\
\hline 2 & $1+$ & & & & & & $6+$ & \\
\hline 3 & & $2+$ & & & & & & \\
\hline 4 & & & $3+$ & & & & & \\
\hline 5 & & & & $4+$ & & & & \\
\hline
\end{tabular}

senescence ultimately becomes a key factor affecting krill availability. Indeed, by the time krill reach Age 5+, they are not only approaching the limits of their life span (now widely accepted as 5 to $6 \mathrm{yr}$; Knox 1994, Siegel \& Kalinowski 1994), but the cohort in general has been subjected to several years of predation and other forms of mortality. The possible effects of senescence are not intuitively obvious by inspection of size-class distributions alone (e.g. Table 3), but may explain why Class 1 ice years are invariably associated with the lowest measures of krill abundance within ice cycles (Table 5).

Although any model of krill age structure will be equivocal by default until better size-age relationships are established, the dynamics implied by Tables 3, 5 \& 6 (i.e. a population structure of larger, older krill being associated with low abundance) do not seem to be unique to the Palmer Station region. Low krill biomass and a population structure composed of predominantly larger, older individuals and, conversely, high krill biomass and smaller, younger individuals, have (not surprisingly) also been documented at South Georgia (Murphy et al. 1998, Reid et al. 1999a,b, Murphy \& Reid 2001, Reid et al. 2002), and indeed appears to be part of a coherent, large-scale pattern linking this region to similar dynamics near Elephant Island (Kawaguchi et al. 1997, Brierley et al. 1999, Watkins 1999, Hewitt \& Linen Low 2000, Reid et al. 2002). Given the previously discussed concurrence in the temporal emergence and spatial expression of strong krill age classes between the 3 regions, a key conclusion suggested by our analyses is that the krill population structure may have similar implications to the spatial and temporal distribution of krill biomass over the entire range of krill in these 3 regions, not just in the sectors of sea ice influenced by the ACW.

\section{Predator foraging performance}

The factors that can influence Adélie penguin FTDs are complex (e.g. Ballard et al. 2001), and some can operate independently of changes in prey availability. These may include residual summer sea ice or distance to the ice edge (Ainley \& LeResche 1973, Ainley et al. 1998), for example, or effects induced by genderspecific behaviors or chick development phase (Clarke et al. 1998, Clarke 2001). It is highly unlikely, however, that these were confounding elements in this study. Ice in the Palmer Station area during January and February when the FTD data were obtained was negligible even during the coldest seasons, and permanent sum- 
mer ice is typically only found in the Marguerite Bay region 300 to $500 \mathrm{~km}$ to the south (cf. Stammerjohn \& Smith 1996). We also controlled for possible effects due to interannual variability in chick development and biases that might have arisen through over-representation of one gender over the other (see 'Materials and methods').

On the other hand, our findings concur with those of Chappell et al. (1993), who suggested, based on the only other major study of Adélie penguin foraging ecology near Palmer Station, that prey capture by this species may be limited by its ability to find krill, as opposed to its ability to efficiently exploit krill once located. Indeed, this seems implicit in Fig. 4b, which indicates that FTDs do not change in direct proportion to changes in krill abundance, but rather exhibit a pattern of variability that is dependent on whether abundances fall above or below a threshold krill density. Above this threshold density, FTDs eventually plateau, while below it they continue to increase with decreasing krill abundance, implying a disproportional sensitivity to periods of reduced krill availability. Consistent with this observation, we suggest that these dynamics can be attributed directly to the effects that a non-random krill population structure imposes on krill availability, but add that changes in krill abundance alone are probably not the only factors affecting these interactions. More specifically, we propose that following the recruitment events that attend Class 2 ice years within ice cycles, the effects of cohort senescence on abundance and of krill reproductive behavior on spatial distribution become interactive, leading ultimately to episodic 'environmental crunches' (Wiens 1989) manifested as particularly long FTDs during the Class 1 ice years of the succeeding ice cycles (e.g. Table 4, Fig. 4a).

What leads us to this conclusion is that krill spatial distribution (inferred from changes in annual population size structures and age during the summer spawning season), also seems to influence FTDs, especially during periods of low krill abundance. This is evident when comparing FTDs and the respective krill population size structures during years of similarly high or similarly low krill abundances. For example, during 1991/92, 1992/93 and 1993/94, years of similar, high krill abundances (Table 5, Fig, 4a) the mean FTDs exhibited little variability (Table 4) despite significant annual differences in the prevailing population size structures (Table 2). In contrast, during 1989/90 and 1994/95, years of similar, low krill abundances (Table 5, Fig. 4a), the mean FTDs were both significantly different (Table $4: 14.33 \pm 5.44$ vs $25.02 \pm 8.41 \mathrm{~h}$ ), and clearly associated with different krill population size structures. Thus, although both these years included 36 to $40 \mathrm{~mm}$ krill as one of the significant size modes in the diet (Table 2), 2 additional smaller modes (26 to 30,31 to $35 \mathrm{~mm}$ ) prevailed in 1989/90, but only a larger mode (41 to $45 \mathrm{~mm}$ ) in 1994/95.

If one considers that $90 \%$ of all female krill become fully mature and spawn for the first time at 36 to $39 \mathrm{~mm}$ total length (Siegel \& Loeb 1994, ca. 34 to $37 \mathrm{~mm}$ based on our measurement techniques), the most obvious explanation for the shorter FTDs during 1989/90 versus the longer FTDs during 1994/95 is that penguins were feeding on smaller, sexually immature krill distributed over the inner shelf during 1989/90 as opposed to larger, sexually mature forms distributed over the outer shelf during 1994/95 (Table 2). However, as a general causal explanation, these dynamics are only in part supported by the FTD data. Based on average Adélie penguin swimming speeds $\left(2 \mathrm{~m} \mathrm{~s}^{-1}\right.$; Culik \& Wilson 1991), birds in 1994/95 could not have reached, foraged and returned from the outer shelf (ca. $160 \mathrm{~km}$ from Palmer Station) in the time suggested by the mean FTDs $(25.02 \pm 8.41 \mathrm{~h}$, Table 4). Indeed, considering the overall mean FTDs (Table 4), a liberal interpretation of foraging range based on swimming speeds could place birds within $90 \mathrm{~km}$ of Palmer Station in some years, but within a more realistic 10 to $15 \mathrm{~km}$ in most years if prey capture times are considered (see Chappell et al. 1993). This concurs with other local observations, including at-sea surveys (Fraser \& Trivelpiece 1996) and, importantly, implies a predatorprey system that actually appears to be very closely coupled in summer with inner shelf rather than outer shelf processes.

Following Chappell et al.'s (1993) conclusions, therefore, the factor most likely to change as krill abundances decrease is search time, which suggests a modified explanation of how krill spatial distribution may interact with abundance to affect FTDs. As implied by Fig. 4b, Adélie penguins still require a minimum FTD as krill abundances increase above a threshold level, suggesting that abundance may mask any effects on search time due to krill spatial distribution. However, given the apparent sensitivity of FTDs to a decrease in krill abundance below the threshold level, any factor that reduces search time would probably be reflected as shorter FTDs. Young, non-reproducing krill could constitute such a factor during years of low krill abundance because, unlike adults, they are both nonmigratory within seasons and, from a spatial perspective, tend to remain over the inner shelf (Siegel 1988, Ross et al. 1996, Lascara et al. 1999). Around Palmer Station, moreover, the presence of these krill leads to considerable foraging by penguins within $1 \mathrm{~km}$ of the colonies (Chappell et al. 1993, W. Fraser unpubl. data), suggesting that these forms also occur over shallower waters close to the land margins. Although more work is needed to understand why large, reproducing krill 
are so consistently present over the inner shelf relatively close to the penguin colonies (but see Fraser \& Trivelpiece 1996, Prézelin et al. 2000), the consequences of episodic recruitment (i.e. Table 3) to FTDs are clear: the decreases in abundance and changes in distribution that occur as the krill cohort ages over the course of 4 to $5 \mathrm{yr}$ inevitably converge, ultimately producing the environmental crunches during Class 1 ice years previously suggested.

On a larger scale, it would appear that these environmental crunches may represent an important juncture in this marine ecosystem insofar as krill availability to predators is concerned. In the Palmer Station FTD time series, 2 such crunches are evident (1990/91 and 1994/95; Table 4, Fig. 4a), and both closely agree ( $\pm 1 \mathrm{yr}$ ) with similar years of increasing foraging trip durations and negative changes in the reproductive output indices of 4 major krill consumers in South Georgia, including the Antarctic fur seal Arctocephalus gazella, the macaroni and gentoo penguins Eudyptes chrysolophus and Pygoscelis papua, and the blackbrowed albatross Thalassarche melanophrys (Boyd et al. 1994, Croxall et al. 1999, Reid \& Croxall 2001). We noted earlier in the text, based on coherent patterns in the temporal emergence and spatial expression of strong krill age classes between these regions, that changes in the krill population size-class structure suggested by Table 3 may have similar consequences for the distribution of krill biomass between Anvers Island and South Georgia. This was confirmed by our analyses. Indeed, the implication is that forcing by these processes is coherent over such large scales that all krilldependent top predators are affected, even those with very different life-histories and ranges of operation.

\section{Implications: krill longevity, climate warming and ecosystem response}

One of the mechanisms by which climate warming may induce changes in ecosystem structure and function is by disrupting the evolved life-history strategies of key component species (Rhodes \& Odum 1996), and certainly one of the most extraordinary features of krill life-history is its remarkable 5 to 6 yr life-span (Nicol 1990, Knox 1994, Siegel \& Kalinowski 1994, Verity \& Smetacek 1996). However, despite broad agreement that this feature is indeed unique among euphausiids, the longevity of Euphausia superba has not been evaluated as a possible causal link between WAP climate warming and ecosystem response. A key implication of our analyses is that krill longevity may be playing a pivotal role in contemporary match-mismatch dynamics, an idea drawn from Cushing's match-mismatch hypothesis and its relationship to understanding recruitment variability in fish (review by Cushing 1995). Here we look at recent, significant ecological changes in the WAP and Scotia Sea regions, and suggest that a mismatch between krill life span and the timing of winter sea ice development may account for many of the observed trends.

Our thesis is based on 2 observations. The first is that sea ice maxima in the WAP region, which provide the conditions favorable to the generation of strong krill year classes, have been rare, occurring on average only once every 4 to $5 \mathrm{yr}$ for most of the last 3 decades (Fig. 2). Krill life span is clearly the essential feature bridging this gap, with the result that at least 1 strong year class has been generated per ice cycle over the same time period. This, in our view, is one of the most significant implications of the patterns evident in Table 3, although Table 6 provides a better perspective of the implied age-specific dynamics. These strong age classes apparently persist in the environment only through Age 6+, which not only agrees with most contemporary estimates of krill longevity (see citations in foregoing paragraphs), but also suggests that the critical maximum age by which reproduction has to occur is approximately Age 5+, or during Class 1 ice years. Another important implication, however, is that if krill lifespan fails to bridge the number of years that elapse between winters of ice maxima, cohort senescence overtakes the population (i.e. based on Table 6, there is no evidence that statistically significant numbers of krill survive beyond Age 6+), with the obvious consequence that most members of the dominant age class die before they can reproduce and contribute to the next generation of recruits (cf. Finch 1990). The second observation is that although sea ice maxima occur on average every 4 to $5 \mathrm{yr}$, 6 yr elapsed between the ice cycles that began with the winters of 1980 and 1986 (Fig. 2), a gap that is unique in the contemporary WAP sea ice record (Stammerjohn \& Smith 1996, Hewitt 1997, Jacobs \& Comiso 1997, Smith et al. 2003), and which we suggest had a major impact on regional ecological processes. The reason is that while the decade apparently began with 2 strong (1979/80, 1980/81) and 1 moderately strong (1981/82) krill age classes (Loeb et al. 1997, Siegel et al. 2002), their hypothetical ages by the $1986 / 87$ spawning season $(7+, 6+$ and $5+$, respectively) would imply that only the 1981/82 year class remained sufficiently abundant to contribute significantly to reproduction and recruitment. Indeed, the notable factor here is that the 1980/81 year class resulted in the highest krill densities recorded to date in the Elephant Island region (Table 5). We thus postulate that the loss of most of this cohort and its reproductive potential to senescence must have had major ecological consequences, and this agrees with major regional-scale changes in krill and their predators.

For example, the lowest krill abundances in the Elephant Island time series were recorded in 1990 (Table 5); biomass and density anomalies also changed 
from predominantly positive before 1985 to negative after 1987 through 1995 (Siegel et al. 1998). Based on data of Woehler et al. (2001), Adélie penguin populations at 2 WAP localities (Palmer Station and King George Island) and in the South Orkney Islands (Signy Island) to the east were stable or increasing through the late 1980s and have decreased significantly post1990. Trends in chinstrap (Pygoscelis antarctica) and gentoo ( $P$. papua) penguin populations, however, were less consistent between these regions, with founder colonies increasing at Palmer Station, but larger populations decreasing elsewhere. In contrast, in South Georgia, all populations of the island's 4 major krilleating predators showed post-1990 declines versus stable or increasing pre-1990 trends (Reid \& Croxall 2001). Some related trends are also interesting. For example, the birth weight of male and female Antarctic fur seals showed a positive trend though 1990 and a negative trend thereafter, which was also true for trends in the arrival weight of male and female macaroni penguins. Finally, there is evidence that the contribution (by weight) of krill in the diets of macaroni penguins began to decline significantly around 1991, especially post-1995 (Reid \& Croxall 2001).

Verity \& Smetacek (1996) postulated that the architecture linking predators and prey may be better understood by viewing it as a product of how marine systems select the life-histories of the taxa that spearhead system fluxes. This is the perspective from which we have approached the questions addressed in this study. Reid \& Croxall (2001) proposed that the recent variability evident in South Georgia top predator populations signals a 'system change' in the marine ecosystem, but provided no mechanism that reasonably accounts for the very tight temporal coupling in physical and biological processes implied by such change. Although the system is clearly too complex to attribute causality in its variability to any single factor, the cohort senescence hypothesis we advance identifies specific dynamics that may explain why the system changed so abruptly between the late 1980s and early 1990s. Another implication of this model is that the variability in climate and sea ice conditions now apparent in the modern record must have prevailed at some point(s) in Euphausia superba's evolutionary past. Krill life-span may thus be viewed as an evolved strategy to minimize mismatches in this highly variable marine environment. However, given the essential role of krill in this ecosystem, and the rate at which climate is warming the region, lifespan may also be viewed as the 'weak link' in the mechanistic processes maintaining ecosystem structure and function. This is because multiple age classes buffer the population from rapid changes in abundance (Siegel et al. 1998), yet the trend since the early 1980s signals a transition towards populations in which age class structure is dominated by single, strong cohorts (e.g. Table 3). If our hypothesis is correct, this ecosystem has become increasingly vulnerable to climateinduced perturbations, as one could deduce that 2 or more closely spaced senescence events would have devastating consequences to its structure and function.

Acknowledgements. The research described in this paper was supported by long-term funding from the National Marine Fisheries Service and National Science Foundation grants 7421374, 7615350, 8918324, 9011927, 9103429, $9320115,9505596,9632763$. We are grateful for the assistance provided by the more than 20 students and technicians who have assisted the data collection effort over the years, and for the leadership given our field teams by Brent Houston, Donna Patterson, Eric Holm, Peter Duley and Matt Irinaga. Dr. Christine Ribic provided invaluable statistical advice and analyses, and comments on an earlier draft by Dr. David Ainley and 2 anonymous reviewers greatly improved the manuscript. This is Palmer LTER contribution no. 246.

\section{LITERATURE CITED}

Ainley DG (2002) The Adélie penguin: bellwether of climate change. Columbia University Press, New York

Ainley DG, LeResche RE (1973) The effects of weather and pack ice conditions on breeding in Adélie penguins. Condor 75:235-239

Ainley DG, LeResche RE, Sladen WJL (1983) Breeding biology of the Adélie penguin. University of California Press, Berkeley, Los Angeles, CA

Ainley DG, Sydeman WJ, Parrish RH, Lenarz WH (1993) Oceanic factors influencing distribution of young rockfish (Sebastes) in central California: a predator's perspective. Calif Coop Ocean Fish Invest Rep 34:133-139

Ainley DG, Ribic CA, Fraser WR (1994) Ecological structure among migrant and resident birds of the Scotia-Weddell confluence region. J Anim Ecol 63:347-364

Ainley DG, Wilson PR, Barton KR, Ballard G, Nur N, Karl B (1998) Variation in foraging patterns of Adélie penguins to changing pack-ice conditions. Polar Biol 20:311-319

Atkinson A, Ward P, Hill A, Brierley AS, Cripps GC (1999) Krill-copepod interactions at South Georgia, Antarctica. II. Euphausia superba as a major control on copepod abundance. Mar Ecol Prog Ser 176:63-79

Ballard G, Ainley DG, Ribic CA, Barton KR (2001) Effect of instrument attachment and other factors on foraging trip duration and nesting success of Adélie penguins. Condor 103:481-490

Boyd IL, Arnould JPY, Barton T, Croxall JP (1994) Foraging behaviour of Antarctic fur seals during periods of contrasting prey abundance. J Anim Ecol 63:703-713

Brierley AS, Demer DA, Watkins JL, Hewitt RP (1999) Concordance of interannual fluctuations in acoustically estimated densities of Antarctic krill around South Georgia and Elephant Islands: biological evidence of same-year teleconnections across the Scotia Sea. Mar Biol 134:675-681

Cairns DK (1987) Seabirds as indicators of marine food supplies. Biol Oceanogr 5:261-271

Cairns DK (1992) Bridging the gap between ornithology and fisheries science: use of seabird data in fish stock assessment models. Condor 94:811-824

CCAMLR (Commission for the Conservation of Antarctic Marine Living Resources) (1992) CEMP Standard Methods. CCAMLR, Hobart 
Chappell MA, Shoemaker VH, Janes DN, Maloney SK, Bucher TL (1993) Energetics of foraging in breeding Adélie penguins. Ecology 74:2450-2461

Clarke J (2001) Partitioning of foraging effort in Adélie penguins provisioning chicks at Béchervaise Island, Antarctica. Polar Biol 24:16-20

Clarke J, Manly B, Kerry K, Gardner H, Franchi E, Corsolini S, Focardi S (1998) Sex differences in Adélie penguin foraging strategies. Polar Biol 20:248-258

Croxall JP, Reid K, Prince PA (1999) Diet, provisioning and productivity of marine predators to differences in availability of Antarctic krill. Mar Ecol Prog Ser 177:115-131

Culik BM, Wilson RP (1991) Energetics of underwater swimming in Adélie penguins (Pygoscelis adeliae). J Comp Physiol 161:285-291

Cushing DH (1995) Population production and regulation in the sea, a fisheries perspective. Cambridge University Press, Cambridge

Daly KL (1990) Overwintering development, growth and feeding of larval Euphausia superba in the Antarctic marginal ice zone. Limnol Oceanogr 35:1564-1567

Fienberg SE (1980) The analysis of cross-classified categorical data. MIT Press, Cambridge, MA

Finch CE (1990) Longevity, senescence and the genome. University of Chicago Press, Chicago

Fraser WR, Ainley DG (1989) US seabird research undertaken as part of the CCAMLR Ecosystem Monitoring Program at Palmer Station 1988-1989. Annual Report. National Marine Fisheries Service, La Jolla, CA

Fraser WR, Trivelpiece WZ (1995a) Palmer LTER: relationships between variability in sea ice coverage, krill recruitment, and the foraging ecology of Adélie penguins. Antarct J US 30:271-272

Fraser WR, Trivelpiece WZ (1995b) Variability in sea ice coverage and long-term change in the diets of Adélie penguins: implications for Southern Ocean ecosystem studies. Report of the Working Group on Ecosystem Monitoring and Management (WG-EMM 95/64, SC-CCAMLR-XIV). CCAMLR, Hobart

Fraser WR, Trivelpiece WZ (1996) Factors controlling the distribution of seabirds: winter-summer heterogeneity in the distribution of Adélie penguin populations. In: Ross RM, Hofmann EE, Quetin LB (eds) Foundations for ecological research west of the Antarctic Peninsula. Antarctic Research Series, 70. American Geophysical Union, Washington, DC, p 257-272

Fraser WR, Ainley DG, Trivelpiece WZ, Huber HR (1988) U.S. seabird research undertaken as part of the CCAMLR Ecosystem Monitoring Program at Palmer Station 1987-1988. Annual Report, National Marine Fisheries Service, La Jolla, CA

Fraser WR, Trivelpiece WZ, Ainley DG, Trivelpiece SG (1992) Increases in Antarctic penguin populations: reduced competition with whales or a loss of sea ice due to global warming? Polar Biol 11:525-531

Furness RW, Nettleship DN (1991) Seabirds as monitors of changing marine environments. In: Bell BD (ed) Proc 20th Congr Int Ornithol, Vol 4. New Zealand Ornithological Congress Trust Board, Wellington, p 2239-2240

Gloersen P, White WB (2001) Reestablishing the Antarctic Circumpolar Wave from one winter to the next. J Geophys Res 106:4391-4399

Hatch SA, Sanger GA (1992) Puffins as samplers of juvenile pollock and other forage fish in the Gulf of Alaska. Mar Ecol Prog Ser 80:1-14

Hewitt RP (1997) Areal and seasonal extent of sea ice cover off the northwestern side of the Antarctic peninsula: 1979 to 1996. CCAMLR Sci 4:65-73
Hewitt RP, Linen Low EH (2000) The fishery on Antarctic krill: defining an ecosystem approach to management. Rev Fish Sci 8:235-298

Hofmann EE, Fraser WR (2003) Environmental implications of Adélie penguin predation on krill: a modeling study. J Mar Res (in press)

Hofmann EE, Klinck JM (1998) Thermohaline variability of the waters overlying the west Antarctic Peninsula continental shelf. Antarct Res Ser 75:67-81

Hofmann EE, Klinck JM, Lascara CM, Smith DA (1996) Water mass distribution and circulation west of the Antarctic Peninsula and including the Bransfield Strait. Antarct Res Ser 70:61-80

Hofmann EE, Klinck JM, Locarnini RA, Fach B, Murphy EJ (1998) Krill transport in the Scotia Sea and environs. Antarct Sci 10:406-415

Jacobs SJ, Comiso JC (1997) Climate variability in the Amundsen and Bellingshausen seas. J Climate 10: 697-709

Karl DM, Christian JR, Dore JE (1996) Microbial oceanography in the region west of the Antarctic Peninsula: microbial dynamics, nitrogen cycle and carbon flux. Antarct Res Ser 70:303-332

Kawaguchi S, Satake M (1994) Relationship between recruitment of the Antarctic krill and the degree of ice cover in the South Shetland Islands. Fish Sci 60:123-124

Kawaguchi S, Ichii T, Naganobu M (1997) Catch per unit effort and proportional recruitment indices from Japanese krill fishery data in Subarea 48.1. CCAMLR Sci 4:47-63

King JC, Turner J (1997) Antarctic meteorology and climatology. Cambridge University Press, Cambridge

Klinck JM (1998) Heat and salt changes on the continental shelf west of the Antarctic Peninsula between January 1993 and January 1994. J Geophys Res 103:7617-7636

Knox GA (1994) The biology of the Southern Ocean. Cambridge University Press, Cambridge

Lascara CM, Hofmann EE, Ross RR, Quetin LB (1999) Seasonal variability in the distribution of Antarctic krill, Euphausia superba, west of the Antarctic Peninsula. Deep-Sea Res 46:925-949

Laws RM (1985) The ecology of the Southern Ocean. Am Sci 73:26-40

Loeb V, Siegel V, Holm-Hansen O, Hewitt R, Fraser W, Trivelpiece W, Trivelpiece S (1997) Effects of sea ice extent and krill or salp dominance on the Antarctic food web. Nature 387:897-900

Murphy EJ (1995) Spatial structure of the Southern Ocean ecosystem: predator-prey linkages in Southern Ocean food webs. J Anim Ecol 64:333-347

Murphy EJ, Reid K (2001) Modelling Southern Ocean krill population dynamics: biological processes generating fluctuations in the South Georgia ecosystem. Mar Ecol Prog Ser 217:175-189

Murphy EJ, Morris DJ, Watkins JL, Priddle J (1988) Scales of interaction between Antarctic krill and the environment. In: Sahrhage D (ed) Antarctic Ocean and resources variability. Springer-Verlag, Berlin, p 120-130

Murphy EJ, Clarke A, Symon C, Priddle J (1995) Temporal variation in Antarctic sea ice: analysis of a long-term fast ice record from the South Orkney Islands. Deep-Sea Res 42:1045-1062

Murphy EJ, Watkins JL, Reid K, Trathan PN and 5 others (1998) Interannual variability of the South Georgia marine ecosystem: biological and physical sources of variation in the abundance of krill. Fish Oceanogr 7:381-390

Nicol S (1990) The age-old problem of krill longevity. BioScience 40:833-836 
Nicol S, Pauly T, Bindoff NL, Wright S, Thiele D, Hosle GW, Strutton PG, Woehler E (2000) Ocean circulation off east Antarctica affects ecosystem structure and sea ice extent. Nature 406:504-507

Parmelee DF (1992) Antarctic birds: ecological and behavioral approaches. University of Minnesota Press, Minneapolis

Peterson RG, White WB (1998) Slow oceanic teleconnections linking the Antarctic Circumpolar Wave with the tropical El Niño-Southern Oscillation. J Geophys Res 103: $24573-24583$

Prézelin BB, Hofmann EE, Klinck JM, Mengelt C (2000) The linkage between Upper Circumpolar Deep Water (UCDW) and phytoplankton assemblages on the west Antarctic Peninsula Continental Shelf. J Mar Res 58:165-202

Priddle J, Croxall JP, Everson IE, Heywood RB, Murphy EJ, Prince PA, Sear CB (1988) Large-scale fluctuations in distribution and abundance of krill - a discussion of possible causes. In: Sahrhage D (ed) Antarctic Ocean and resources variability. Springer-Verlag, Berlin, p 169-182

Quetin LB, Ross RM (1991) Behavioral and physiological characteristics of the Antarctic krill, Euphausia superba. Am Zool 31:49-63

Reid K, Croxall JC (2001) Environmental response of upper trophic-level predators reveals a system change in an Antarctic marine ecosystem. Proc R Soc Lond 268:377-384

Reid K, Barlow KE, Croxall JP, Taylor RI (1999a) Predicting changes in the Antarctic krill, Euphausia superba, population at South Georgia. Mar Biol 135:647-652

Reid K, Watkins JL, Croxall JP, Murphy EJ (1999b) Krill population dynamics at South Georgia 1991-1997, based on data from predators and nets. Mar Ecol Prog Ser 177: 103-114

Reid K Murphy EJ, Loeb V, Hewitt RP (2002) Krill population dynamics in the Scotia Sea: variability in growth and mortality within a single population. J Mar Syst 36:1-10

Rhodes OE Jr, Odum EP (1996) Spatiotemporal approaches in ecology and genetics: the road less traveled. In: Rhodes OE Jr, Chesser RK, Smith MH (eds) Population dynamics in ecological space and time. University of Chicago Press, Chicago, p 1-8

Ross RM, Quetin LB (1991) Ecological physiology of larval euphausiids, Euphausia superba (Euphausiacea). Mem Queensl Mus 31:321-333

Ross RM, Quetin LB, Lascara CM (1996) Distribution of Antarctic krill and dominant zooplankton west of the Antarctic Peninsula. Antarct Res Ser 70:199-218

Salihoglu, B, Fraser WR, Hofmann EE (2001) Factors affecting fledging weight of Adélie penguin (Pygoscelis adeliae) chicks: a modeling study. Polar Biol 24:328-337

Siegel V (1987) Age and growth of Antarctic Euphausiacea (Crustacea) under natural conditions. Mar Biol 96: 483-495

Siegel V (1988) A concept of seasonal variation of krill (Euphausia superba) distribution and abundance west of the Antarctic Peninsula. In: Sahrhage D (ed) Antarctic Ocean and resources variability. Springer-Verlag, Berlin, p 219-230

Siegel V, Kalinowski J (1994) Krill demography and smallscale processes: a review. In: El-Sayed SSZ (ed) Southern Ocean ecology: the BIOMASS perspective. Cambridge University Press, Cambridge, p 145-163

Siegel V, Loeb V (1994) Length and age at maturity of Antarctic krill. Antarct Sci 6:479-482

Siegel V, Loeb V (1995) Recruitment of Antarctic krill Euphausia superba and possible causes for its variability. Mar Ecol Prog Ser 123:45-56
Siegel V, Mare W de la, Loeb V (1997) Long-term monitoring of krill recruitment and abundance indices in the Elephant Island area (Antarctic Peninsula). CCAMLR Sci 4:19-35

Siegel V, Loeb V, Groger J (1998) Krill (Euphausia superba) density, proportional recruitment and absolute recruitment and biomass in the Elephant Island region (Antarctic Peninsula) during the period 1977 to 1997. Polar Biol 19: 393-398

Siegel V, Bergström B, Mühlenhardt-Siegel U, Thomasson M (2002) Demography of krill in the Elephant Island area during summer 2001 and its significance for stock recruitment. Antarct Sci 14:162-170

Smith RC, Stammerjohn SE (2001) Variations of surface air temperatures and sea ice extent in the western Antarctic Peninsula (WAP) region. Ann Glaciol 33:493-500

Smith RC, Baker KS, Fraser WR, Hofmann EE and 7 others (1995) The Palmer LTER: a long-term ecological research program at Palmer Station, Antarctica. Oceanography 8: $77-86$

Smith RC, Stammerjohn SE, Baker KS (1996) Surface air temperature variations in the western Antarctic Peninsula region. Antarct Res Ser 70:105-121

Smith RC, Baker KS, Stammerjohn SE (1998) Exploring sea ice indexes for polar ecosystem studies. BioScience 48 : $83-93$

Smith RC, Ainley D, Baker K, Domack E and 7 others (1999) Marine ecosystem sensitivity to climate change. BioScience 49:393-404

Smith RC, Fraser WR, Stammerjohn SE (2003) Climate variability and ecological response of the marine ecosystem in the western Antarctic Peninsula (WAP) region. In: Greenland D, Goodin D, Smith R (eds) Climate variability and ecosystem response at long-term ecological research sites. Oxford Press, Oxford, p 158-173

Stammerjohn SE, Smith RC (1996) Spatial and temporal variability of western Antarctic Peninsula sea ice coverage. Antarct Res Ser 70:81-104

Sunada JS, Yamashita IS, Kelly PR, Gress F (1981) The brown pelican as a sampling instrument of age group structure in the northern anchovy population. Calif Coop Ocean Fish Invest Rep 22:65-68

Verity PG, Smetacek V (1996) Organism life cycles, predation and the structure of marine pelagic ecosystems. Mar Ecol Prog Ser 130:277-293

Volkman NJ, Presler P, Trivelpiece W (1980) Diets of pygoscelid penguins at King George Island, Antarctica. Condor 82:373-378

Watkins JL (1999) A composite recruitment index to describe interannual changes in the population structure of Antarctic krill at South Georgia. CCAMLR Sci 6:71-84

White WB, Peterson RG (1996) An Antarctic circumpolar wave in surface pressure, wind, temperature and sea ice extent. Nature 380:699-702

Wiens JA (1989) The ecology of bird communities, Vol 2. Processes and variations. Cambridge University Press, Cambridge

Wilson RP (1984) An improved stomach pump for penguins and other seabirds. J Field Ornithol 55:109-112

Wilson PR, Ainley DG, Nur N, Jacobs SS, Barton KJ, Ballard G, Comiso JC (2001) Adélie penguin population change in the Pacific sector of Antarctica: relation to sea ice extent and the Antarctic Circumpolar Current. Mar Ecol Prog Ser 213:301-309

Woehler EJ, Cooper J, Croxall JP, Fraser WR and 9 others (2001) A statistical assessment of the status and trends of Antarctic and subantarctic seabirds. SCAR/CCAMLR/ NSF, Bozeman, MT

Submitted: November 13, 2001; Accepted: September 5, 2003 Proofs received from author(s): December 17, 2003 